\title{
Bleeding Edge of Postmodernism: Metamodern Writing in the Novel by Thomas Pynchon
}

\author{
SIMON RADCHENKO
}

\begin{abstract}
Many different models of contemporary novel's description arose from the search for methods and approaches of post-postmodern texts analysis. One of them is the concept of metamodernism, proposed by Timotheus Vermeulen and Robin van den Akker and based on the culture and philosophy changes at the turn of this century. This article argues that the ideas of metamodernism and its main trends can be successfully used for the study of contemporary literature. The basic trends of metamodernism were determined and observed through the prism of literature studies. They were implemented in the analysis of Thomas Pynchon's latest novel, Bleeding Edge (2013). Despite Pynchon being usually considered as postmodern writer, the use of metamodern categories for describing his narrative strategies confirms the idea of the novel's post-postmodern orientation. The article makes an endeavor to use metamodern categories as a tool for post-postmodern text studies, in order to analyze and interpret Bleeding Edge through those categories.
\end{abstract}

Keywords: meta-modernism; postmodernism; Thomas Pynchon; oscillation; new sincerity

How can we study something that has not been completely described yet? Although discussions of a paradigm shift have been around long enough, when talking about contemporary literary phenomena we are still using the categories of feeling rather than specific instruments. Perception of contemporary literature as post-postmodern seems dated today. However, Joseph Tabbi has questioned the novelty of post-postmodernism as something new, different from postmodernism and proposes to consider the abolition of irony and postmodernism (Tabbi 2017).

A variety of different approaches have appeared recently to describe and prove the death of postmodernism. Alan Kirby proclaims this death looking at the dates when the core postmodern texts were published: "Most of the undergraduates who will take 'Postmodern Fictions' this year will have been born in 1985 or after, and all but one of the module's primary texts were written before their lifetime. Far from being 'contemporary', these texts were published 
in another world, before the students were born" (2006: 34). Thinking that all these texts and their disciples were oriented towards the past, he offers the idea of pseudo-modernism as a concept where the main way for accepting a text is interaction ${ }^{1}$. The same ideas about the rise of the new age are given in Irmtraud Huber's book where she claims about art: "[A]fter and because of deconstruction it seeks to be reconstructed" (2014: 7).

But not only the deconstructive concepts of postmodernism seem to be passé. Frederic Jameson says that postmodernism with its "here and now" way of thinking loses its dimensionality and leaves the world in the "total collapse of the depth model. [...] The whole "hermeneutic model" is rejected as "depth is replaced by surface" (1991: 12). Extending this metaphor, Brendan Dempsey writes that contrary to the postmodern loss of the transcendental truth and depth, "[f]or some of this generation are daring to imagine transcendence again” (Dempsey 2015).

It looks like something that had been declared for decades has already happened and the death of postmodernism does not need to be proven again. At the moment there are many practices going on in contemporary literature and art. They not only include pseudo-modernism and reconstruction, but also performatism or the aesthetic of trust, as well as others ${ }^{2}$.

In these circumstances, the important part of studying the contemporary novel (or any other genre) is to employ the instruments that will reveal its core ideas. Obviously, talking about post-postmodernism, searching for the right code requires a number of attempts before the more or less complete scheme of the new structure is created. For now, the concept of metamodernism is probably one of the most complex ideas that integrates a variety of tools allowing us to draw some conclusions. The reason for it appropriateness lies in the endeavour to depict the structure of a new post-postmodern feeling.

The first essay that describes contemporary processes using the term metamodernism was proposed in 2010 by Timotheus Vermeulen and Robin van den Akker. The authors associate the new trends in culture with technological and scientific achievements, political, ecological and social changes and also with the development of new ideas in art and philosophy (see Vermeulen and van den Akker 2010). However, these trends are not only connected with the

1 At the same time he notices the extremely poor cultural aspect of this approach because the cultural products without interaction with their consumers appear to be empty.

2 See, for example, works such as Alan Kirby, The Death of Postmodernism and Beyond (2006); Irmtraud Huber, Literature after Postmodernism: Reconstructive Fantasies (2014); Raoul Eshelman, Performatism or the End of Postmodernism (2008); Ihab Hassan, The Postmodern Turn: Essays on Postmodernism and Culture (1987). 
Bleeding Edge of Postmodernism: Metamodern Writing in the Novel by Thomas Pynchon

progress itself but also with the striving to counter postmodernism. That is the reason why metamodernism is in some features in opposition to it and at the same time is under its influence.

The main construct of metamodernism and all art strategies connected to it, thus, is the infinite oscillation between the modern and postmodern ideas. This manifests itself as the belief in the transcendent truth and the failure to reach it; the need for choice and doubts about what to choose; postmodern skepticism and new sincerity. Vermeulen \& van den Akker did not try to explain the meaning of these processes, only to compile and describe them under a single concept.

Later, in Misunderstandings and Clarifications (Vermeulen and Van den Akker 2015) the authors emphasize that metamodernism in their understanding is not a strategy, philosophy or doctrine. Mostly, it is the way to delineate the structure of feelings. Nevertheless, terms and describing strategies that they use generally reflect the existing situation in contemporary literature. So, the attempt to act with this description as if ${ }^{3}$ it embodied a more or less efficient research instrument seems to be fruitful. After all, the authors consider the phenomenon of cultural philosophy as a product of culture. This product, "Philosophy - or thinking in a broader sense - exists in the social context, not in a vacuum" (Syundukov and Svishchenko 2016). To some extent, literature is also a similar product. It means that in literature the manifestations of metamodern feeling that researchers detect in the modern achievements of philosophy, as well as in the other arts, can be found.

The use of the features of metamodernism in literary research demands careful adoption of them for this purpose, defining the basics of their principles and meanings. I will try to name and describe (once again) some of them, indicating their place in the text and making an attempt to show the connection of their display in the text with the metamodern feeling. This is an impossible task in one article (or even in one book), so this text is just an endeavour to give a brief description.

The core principle of metamodernism is oscillation: permanent movement between different poles. The nature of this oscillation lies in human feelings beyond postmodernism; the desire to reach them and the doubts about the possibility of doing this. It requires a belief in some transcendent truth (no matter if it is possible or not to find it) and the search for it. As the search

"As if" is (according to Vermeulen and van den Akker) the way of thinking that describes the metamodern worldview very well. They also point to the reflection of "as if" thinking in the Kantianism. 
becomes more active, the researcher oscillates back to postmodern skepticism and then back again. At last, it means doubts of choosing without the chance to choose - because " $[\mathrm{t}]$ here are no necessary terms, methods or strategies for representing the future and moving to it" (Syundukov and Svishchenko 2016). The inefficiency of this search reveals the feeling of nostalgia for the past, when choosing was not needed and total skepticism without taking any position was allowed. The need to take a stand also forces us to acknowledge the experiences of the past which it is impossible to do with postmodern irony. All of this will reveal to us the metamodern hero - the nostalgic character who cannot make a decision despite his efforts, thus he oscillates between all the possible choices (including the choice of not to choose). On the level of narrative strategy, it means movement between the modern and postmodern methods and writing approaches, and, in general, between the modern and postmodern worldviews.

Irony and skepticism are some of the main parts of postmodern worldview that have been reconsidered in the last years. As soon as a human being needs to take a decision, he/she also needs to believe that the right choice is possible. That is why irony cannot be the way of thinking any longer. Surely, it is important to save it for communication. However, the metamodern person needs to think, look and desire from the prospect of feeling. The desire for this feeling, mainly called the "new sincerity" or affect was noticed and proposed in the previous century. David Foster Wallace was one of the authors who described this sincerity and its value as the new way of thinking and writing: "The new rebels might be the ones willing to risk the yawn, the rolled eyes, the cool smile, the nudged ribs, the parody of gifted ironists, the "How banal." Accusations of sentimentality, melodrama. Credulity" (1993: 193). Besides the wish to have feelings and to act according to them, the "new sincerity" leads to the belief (mostly blind) in the existence of the transcendent and unreachable truth somewhere beyond the horizon of the known. This belief is the motivator for acting and searching, as if it were possible to find the truth. It motivates the metamodernist despite the postmodern understanding that the search is fruitless, so the metamodernist is ready to believe. This determines the naïveté of the metamodernist - faith in spite of reason.

Beside the total skepticism and sneer, the postmodern text is very rich in descriptions, metaphors and word surplus. Postmodern verbosity and excess of expressions is connected with the "general confusion and mockery of everything [...] "cultural indirection", or, briefly, a quotation" (Rudnev 2010). The exact description of such a state is the famous quote about postmodern 
Bleeding Edge of Postmodernism: Metamodern Writing in the Novel by Thomas Pynchon

love, given by Umberto Eco ${ }^{4}$. Thus, the important part of the postmodern worldview - the revision of modern experiences, ultimate irony and the defensive mockery - is being implemented through the wall of words and the intertextual stream.

As the "new sincerity" arises, ironic mockery of postmodernism loses its influence on the language of the text. The author, as well as the characters, is much more practical in the means of expression. The oscillating nature of metamodernism provokes some postmodern manifestations of style but the communicative method is based also on metamodern utility. It means that irony and skepticism in texts are not the way of thinking any longer and they have no power to define the style of communication. There is always a practical communicative meaning. At the same time the core of the text is not the sneer behind the intertextual wall but the sincerity with a much shorter mode of expression. The intertextual massif itself also fades away because the cultural references and allusions are the way to depict and describe. They also have a practical purpose, so they are as accurate as possible. In this way the extensive ironic postmodern descriptions were exchanged for the wish to reveal feelings and to transmit them to another human being.

All mentioned aspects - the sincerity, the willingness to connect with another human being and to transmit feelings - have the same origin: the desire to be a part of something more, to be bound with something. Nicoline Timmer calls it "a structural need for a 'we' (a desire for connectivity and sociality)" (Timmer 2010: 359). In contrast to the postmodern individuality and the wish to be remarkable, metamodernism reveals the appetence to normalize the environment and avoid the chaos of postmodern deconstruction. In the search for the unreachable truth as well as in efforts to choose, the metamodern character looks for sociality and for the possibility of belonging to any kind of system. Even without the marked borderlines, this character is aware of their

4 The postmodern reply to the modern consists of recognizing that the past, since it cannot really be destroyed, because its destruction leads to silence, it must be revisited: but with irony, not innocently. I think of the postmodern attitude as that of a man who loves a very cultivated woman and knows that he cannot say to her 'I love you madly', because he knows that she knows (and that she knows he knows) that these words have already been written by Barbara Cartland. Still, there is a solution. He can say 'As Barbara Cartland would put it, I love you madly'. At this point, having avoided false innocence, having said clearly that it is no longer possible to speak innocently, he will nevertheless have said what he wanted to say to the woman: that he loves her in an age of lost innocence. If the woman goes along with this, she will have received a declaration of love all the same (Eco 1994: 67-68). 
existence, the systemic and hierarchical nature of the metamodern. "Metamodernism reintroduces hierarchies as a unit of analysis, as a reaction against the postmodern relativistic attitude stating that all hierarchies are bad", as it was pointed by Hanzi Freinacht (2015). The admission of hierarchy and dedication to the system is constantly in evidence in metamodern texts. As the metamodern character needs the feeling of belonging and the sociality, one of the goals is to find or create an identity. Defining who he/she is, the character makes it possible to belong to the system - so the search for an identity is an important motivation for him.

All of this would be impossible without the constructive nature of metamodernism. Vice versa, the belief, naïveté and desire for identity produce the constructive potential for it. As an obvious consequence of the postmodern era, one of the main metamodern desires is to create or reconstruct the world on a cleaned postmodern soil. Robin van den Akker says that among the main trends of metamodernism we have "the attempts of constructive participation, pointed on the reconstruction of what were deconstructed" (Syundukov and Svishchenko 2016). The belief in the existence of the truth and search held by metamodernists has a particular target: the reconstruction of the oecumene according to the rules of their systems and groups. The wish to create is also the reason for reducing mockery and skepticism. Still existing in language and humour, they are not the instruments of reconstruction and their role is diminished. At all levels of the text this constructive willingness is, first of all, the answer to collapse and destruction of the previous models or their signs. This desire is the basic point of post-post, the reason for the emergence of new feelings.

Five trends, mentioned above - oscillation, new sincerity, language utility, belonging to the system and constructive nature - are the important points of the metamodern agenda, implemented to the contemporary literary process. A huge variety of metamodern trends has been noticed and mentioned by different researchers (Syundukov and Svishchenko 2016; Freinacht 2015). Nicoline Timmer composed the list of post-postmodern characteristics of the novel (Timmer 2010: 359-362). The described categories are more or less among them as well. As these lists were created on the grounds of studies of contemporary culture and literature, as the result of observation, it is possible to use the method in reverse order. Based on the notes on metamodernism and its description, the listed trends can serve as an instrument for revealing the metamodern nature of the text.

The post-postmodern novels (because they are topical) have become a very engrossing subject to study (Timmer 2010; Huber 2014; Kirby 2009) 
and review (see Feßler 2015; Polyarinov 2014 etc.) during the last decade. Researchers and literary critics use a number of different instruments and concepts while writing about them. As the territory of new literary trends is not marked yet, it is reasonable to look at the newest novel of the author who is deemed a postmodernist from the metamodern position.

Thomas Pynchon's latest novel Bleeding Edge, published in 2013, drew the attention of the press from the moment of its announcement. More than once it was reviewed from different points of view - placing an emphasis on the setting, plot or typical for Pynchon the theme of the digitalization and informatization of the world (see Pappademas 2013; Stevenson 2013; Rolls 2013). The aspects of the author's style were already studied and described by, for example, Joseph Tabbi (1996; 2002), who analyzes the communications and connections, the role of prognosis and digitalization in a variety of Pynchon's works. These concepts are also present in Bleeding Edge (Tabbi 2017), which make the novel interesting to discuss from the position of Alan Kirby's "digimodernism". The writings of Pynchon have been studied quite intensively for a long time. Despite having been considered a postmodernist, his works in the $21^{\text {st }}$ century are different from his first postmodern novels. Sascha Pöhlmann has already mentioned that "we may have to stop calling Thomas Pynchon a postmodern writer" (Pöhlmann 2010: 9). As he is an active participant in the contemporary literary process, it is possible for Pynchon to move in his novels beyond the postmodern worldview. Thus, it is reasonable to search for new approaches to read and discuss Pynchon's novels. Further I will try to find and describe the examples of the metamodern worldview in Bleeding Edge.

The setting is very important and descriptive in the case of the novel. New York City in 2001 and the events of 9/11 mark the moment of crisis that leads to the paradigm shift. It is possible that these very events mark the start of war against terrorism and produce the understanding that the postmodern mockery should be abandoned at last. As Alan Kirby notes, "postmodernism was interred in its [11 September 2001] rubble" (2006: 37). The feelings and ideas that fill the heroes' consciousness show the changes in the postmodern world and the oscillation between the old and the new, sincerity instead of irony and the desire to construct.

An important part of the novel's plot is dedicated to the search without a beginning or end. Such movement without a particular direction is possible for Maxine Tarnow and other citizens of Pynchon's NYC. Meaningless surfing here is a "part of the experience, part of getting constructively lost" (Pynchon 2013: 76). One of the ideas of metamodern oscillation is to look for something that is beyond the horizon and the desire to search whatever the result may 
be, so - "Before long, Maxine finds herself wandering around clicking on everything, faces, litter on the floor, labels on bottles behind the bar, after a while interested not so much in where she might get to than the texture of the search itself" ( $i b i d$.$) . Even if the goal is clear, it is only the idea that "something$ should be" that provides the continuation of the search:

"Meantime, down here, sooner or later someplace deep, there has to be a horizon between coded and codeless. An abyss."

"That's what you're looking for?"

"Some of us are." (Pynchon 2013: 357)

Using DeepArcher, Maxine oscillates in the desire to search, although in reality her oscillation is connected to doubts when taking decisions. Thus, she does not know what to choose concerning her Certified Fraud Examiner (CFE) status. On the one hand, she did not fill the appeal of decertification - "as days passed, there were always reasons not to, she couldn't afford the legal fees, the appeals process could all be just for show, and the fact remained that colleagues she respected had thrown her out on her ear, and did she really want back into that kind of vindictive surroundings. Sort of thing." (Pynchon 2013: 19). On the other hand, "the certificate's put away in storage, but still hanging on the office wall of my soul" (ibid.). As a metamodern character, she fails to make an assured decision. The same model is drawn in her family relationships. Maxine and Horst are in a position between family and divorce. Maxine describes her Quasi-ex-husband as "nowhere-near-history Horst Loeffler" (Pynchon 2013: 92). Despite Horst's oscillating between the family and not-family, after the events of $9 / 11$ both Loefflers decide to take the position and to admire their family status (to construct a new structure). The same oscillation exists in Maxine's relations with other persons (for instance, Nicolas Windust) or in their actions and positions - like March Keheller who is exiled from her family although she participates in their lives.

The novel itself oscillates between the postmodern and non-postmodern conditions. A lot of postmodern descriptions are provided by Pynchon in every chapter in the novel with an abundance of symbols, citations, narrations etc. NYC of 2001 is amplified many times in Bleeding Edge:

Sid kills the running lights and the motor, and they settle in behind Island of Meadows, at the intersection of Fresh and Arthur Kills, toxicity central, the dark focus of Big Apple waste disposal, everything the city has rejected so it can keep on pretending to be itself, and here unexpectedly at the heart of it is this 100 acres of untouched marshland, directly underneath the North 
Bleeding Edge of Postmodernism: Metamodern Writing in the Novel by Thomas Pynchon

Atlantic flyway, sequestered by law from development and dumping, marsh birds sleeping in safety. (Pynchon 2013: 166)

S. de Bourcier notices, that "in Bleeding Edge the term 'postmodern' has entered Pynchon's lexicon, describing everything from DeepArcher's virtual trains to the architecture of Gabriel Ice's house" (De Boucier 2014). Pynchon uses the concept of postmodernity as a method to describe the environment which is complete and understood but his characters are far from being postmodern ${ }^{5}$. By studying post-postmodern writing, Nicoline Timmer says that "the postmodern methods are in use in post-postmodern literature, but only as the "mode of writing" for this writer's generation" (Timmer 2014: 361).

Despite of the postmodern descriptive method, the characters as well as their style are different - their talk is simplified and aimed at communication, the idea of giving information using the most effective way.

When describing the characters Pynchon uses the stereotypization of images in order to make the characters more visible and their descriptions shorter. For example, Vyrva McElmo is "a West Coast thing, it seems to Maxine. Vyrva is a sweetheart but not nearly time-obsessed enough" (Pynchon 2013: 3). The same with her uptalk manner of speaking. Further, the same description model is used for Tallis who "has perfected the soap-opera trick of managing through all the daylight hours to look turned out for evening activities ... Her image became conflated with those of Heather Locklear, Linda Evans, and Morgan Fairchild, among others" (Pynchon 2013: 125). The association of characters with particular cinema scenes or media persons is also a non-postmodern method, used by Pynchon in the case of, for example, Horst Loeffler, "showing up, like Basil St. John in the life of Brenda Starr" (Pynchon 2013: 92) or Conkling Speedwell: "for a minute she thinks it's Alex Trebek" (Pynchon 2013: 200). Maxine's and other characters' lexicon is filled with media images and associations as well as with abbreviations, media events and slang language: nerd, WYUP, The Deseret, NASDAQ Comic Con etc. The reason for this lies in the desire to be heard and understood. The communication goal is to give and take the accurate information with fewer resources, so stereotypes and well-known images are the most effective descriptive method. They are also the condition of the novel's language utility. Unusually for postmodernism, personages and media resources in Bleeding Edge do not use extra words when there is nothing more to say: "Nobody that

5 Except, probably, Conkling Speedwell and his supernatural nose. 
morning had anything to say, [...] Just the one camera angle, the static telephoto shot of those towers smoldering..." (Pynchon 2013: 324).

The mentioned aims of communication are also the reason for reducing the postmodern citations and mockeries during communication. Instead of the postmodern mode, they try to feel and to reveal it to others. By showing what they feel, they are taking steps to move from irony to sincerity, which, according to Heidi, "has now become another collateral casualty of 11 September because somehow it did not keep the tragedy from happening" (Pynchon 2013: 335). It means that irony is no longer needed, so it vanishes from characters' speeches and actions: "Wave of the future, honeybunch." Irony-free. Unthinkable a year or two ago" (Pynchon 2013: 343). To the contrary, they are making attempts to describe feelings and to talk about them, they decide to be sincere again: "It's still too much for her to get her own head around, how much she's missed him" (Pynchon 2013: 332). No characters of the novel are afraid of being emotional to be afraid, like Reg Despard ("That's when I started to get scared" (Pynchon 2013: 91)) or angry, like March Keheller ("March dropped the bags she was carrying in the filthy slush on the street, gave them a good kick, and screamed as loud as she could, "I hate this miserable shithole of a city!" (Pynchon 2013: 128)). Imitation, as Heidi says, is impossible now. The struggle for sincerity explains the blind belief in something that usually is considered impossible or unnatural: "You're what, forty, fifty years old, and you believe in Santa Claus?" "I do indeed, and if this miserable city is too wised up to deal with it, then they can shove it up their own..." (Pynchon 2013: 397). This childish naïveté is bounded not only with cultural myths like Santa Claus, but with human nature as well: "no, I'm thinking, he can turn. He can still turn away, nobody's that bad, he has to have a conscience, there's time, he can make up for it..." (Pynchon 2013: 421). It is one of the main conditions of metamodern search which means - among other things - admiring the past, remembering it along with another part of sincerity - nostalgia.

Nostalgia is the constant state of all the characters in the novel. Some of them, like Driscoll, recall American media culture - "Friends" and Jennifer Aniston's hair; others, like Igor - old Soviet movies. The novel is enriched with many names and titles of NYC life in 2001 and before. Some song lyrics and band descriptions belong to the beginning of the $21^{\text {st }}$ century, some of them - to the characters' youth. Nostalgia, remembrance of the happy past is the key concept of the nerd party in the setting of 1999 or of the "Joie de Beavre" atmosphere with disco and the "Guns-n-Roses" sound. Maxine, as well as others, feels nostalgia when she is reminded about family days: "Nostalgia lurks, ready to ooze from ambush. Maxine thinks back to when the boys were 
little, the local practice in neighborhood pizza parlors then being to cut slices into small bite-size squares as an accommodation for little kids. When the kid can handle a whole slice, it's a kind of coming-of-age" (Pynchon 2013: 314). She also often recalls the cultural heritage of her past - songs from the mid-nineties, cinema etc.: "[After a pedal-steel break that has always reached in and found Maxine's heart] ... So forth. By which point Maxine is singing along in a pretty focused way, with the wind blowing tears back into her ears, and she's getting looks from drivers in adjoining lanes" (Pynchon 2013: 185-186). The same nostalgia pursues Horst who is obsessed by the culture of his Motherland - the Middle West.

The feeling of nostalgia in the novel is multifunctional - it helps characters not only to be sincere and emotional but also to identify themselves with something since identification is what they use to mark and measure the space around them. Maxine Tarnow constantly identifies herself with her work (exCFE) or most of all with her nationality (she is a Jew). Other characters are also trying to describe themselves through a social or professional group, e.g. nerds, "track-rider community", "nasal forensics" etc. Through these labels characters endeavor to describe themselves and find their place in the novel's space, by regulating the environment that defines their position. With this regulation they try to feel safe, to take the control of their surroundings back. In some characters it leads to the wish to create and follow structures - "behind it is a whole invisible maze of constraints, engineered in, lets you go some places, keeps you out of others. This hidden code of behavior you have to learn and obey. A dump, with structure" (Pynchon 2013: 227). Identity and regulation are important to them because of their need to take up a position as a result of the search. One of the side effects of this wish is their participation in demonstrations and an active social position which leads, according to March Keheller, to admission of responsibility. Bleeding Edge characters know that such participation and belonging is the way to avoid being lonely, scared and jeopardized, so they are trying to create it or at least to believe in it: "they get us, all right, we're all lonely, needy, disrespected, desperate to believe in any sorry imitation of belonging they want to sell us..." (Pynchon 2013: 432).

So far as the desire for identity and regulation is one of the most strongly pronounced feelings of Bleeding Edge characters after 9/11, they need to create or reconstruct systems that will provide them with a feeling of belonging. The constructive power of their wishes, bounded not only with their need for structure and belonging, but also with their naïveté and attempts to avoid destructive irony and postmodern mockery, emerges mostly after 9/11 and gives them an opportunity to reconstruct their social lives after the tragic 
events. Maxine restores her family with Horst and helps her brother-in-law (whose wife is pregnant) to safely quit Gabriel Ice's company. Reconstructing their relationship after 9/11 also works for Eric and Driscoll (though not for long). The general mood is reflected in Ernie's Joe Hill quote: “don't mourn, organize" (Pynchon 2013: 422). This principle works for the entire New York City. The expression of the citizens' readiness to reconstruct is the day of the NYC marathon: "the day of the NYC marathon, seven weeks into post-atrocity, the fearful day still reverberating, what you could call a patriotic atmosphere, thousands of runners come out in memory of 11 September and its victims in defiance of any chance it'll happen again..." (Pynchon 2013: 376). The desire to reconstruct what was destroyed touches not only the real but also the virtual world and brings to life the "...graphics files for a version of NYC as it was before 11 September 2001, before Ms. Cheung's bleak announcement about real and make-believe, reformatted now as the personal city of Zigotisopolis, rendered in a benevolently lighted palette..." (Pynchon 2013: 428). This virtual world allows them to enjoy the NYC-before-9/11 as if nothing had happened, reconstructed with all the specifics and details. In a strange way, the events of 9/11 forced the characters to feel more deeply and to build again. This struggle for the creation of a changed world is the result of a paradigm shift. And one of the turning points of this shift was the collapse of the twin towers.

All of this shows a more or less complete image of Pynchon's Bleeding Edge heroes and their environment - they are full of doubt about the direction of their moves, wishing to find some solid ground of regularity and safety. At the same time they try to continue looking for something that they desperately need: sincerity and an emotional connection with each other. One among a variety of things that helps them to do this is the naivete and belief in the possibility of finishing the search. Such a belief is obviously impossible in postmodern writing.

The examples listed above confirm that Thomas Pynchon's Bleeding Edge fits the description of a post-postmodern novel better than a postmodern one. The text is structured with the concepts of oscillation, sincere feelings instead of irony, utility of character's language symbolism, ideas of belonging to the system and the constructive power that the characters try to use. Following Sascha Pöhlmann, we should join the idea of stopping to call Pynchon a postmodernist, as his last novel is far from being postmodern. Moreover, the novel's narrative fits better another description model that is based on the concept of metamodernism. 
Bleeding Edge of Postmodernism: Metamodern Writing in the Novel by Thomas Pynchon

\author{
Simon Radchenko \\ Simon.radchenko@gmail.com \\ Str. Ernsta, 2, app. 201 \\ $03048 \mathrm{Kiev}$ \\ UKRAINE / УKPAÏHA
}

\title{
Bibliography
}

De Bourcier, S. 2014. Reading McHale Reading Pynchon, or, Is Pynchon Still a Postmodernist?. - Orbit: A Journal of American Literature, 2(2): 1-16. https://doi. org/10.7766/orbit.v2.2.68.

Dempsey, B. 2015. [Re]construction: Metamodern 'Transcendence' and the Return of Myth. - Notes on Metamodernism, http://www.metamodernism.com/2015/ $10 / 21$ /reconstruction-metamodern-transcendence-and-the-return-of-myth/ (23.02.2018).

Eco, U. 1994. Reflections on the Name of the Rose. London: Minerva.

Feßler, N. 2015. Locked Up: Siri Hustvedt's “The Blazing World”. - Notes On Metamodernism, http://www.metamodernism.com/2015/09/07/locked-up-sirihustvedts-the-blazing-world/ (23.02.2018).

Freinacht, H. 2015. 5 things that make you metamodern. - Metamoderna, http:// metamoderna.org/5-things-that-make-you-metamodern?lang=en (23.02.2018).

Huber, I. 2014. Literature after Postmodernism: Reconstructive Fantasies. New York: Palgrave Macmillan.

Jameson, F. 1991. Postmodernism, or the Cultural Logic of Late Capitalism. Durham: Duke University Press.

Kirby, A. 2009. Digimodernism: How New Technologies Dismantle the Postmodern and Reconfigure our Culture. New York/London: Continuum.

Pappademas, A. 2013. Thomas Pynchon's “9/11 Novel” Bleeding Edge: Let the Wild Prognosticating Begin. - Grantland, 26.02, http://www.grantland.com/.

Pöhlmann, S. 2010. Introduction: The Complex Text. - S. Pöhlmann, ed., Against the Grain: Reading Pynchon's Counternarratives. Amsterdam: Rodopi, 9-34.

Polyarinov, A. 2014. David Foster Wallace, "Infinite Jest". - Journal of Foreign Literature. Blog of Alexey Polarinov, http://polyarinov.livejournal.com/50610.html (23.02.2018).

Pynchon, T. 2013. Bleeding Edge. New York: The Penguin Press.

Rolls, A. 2013. Review of Bleeding Edge, by Thomas Pynchon. - Orbit: Writing Around Pynchon 2, 1-6. https://doi.org/10.7766/orbit.v2.1.51

Rudnev, V. P. 2010. Postmodernism. - Natural Scientific Researches of the Creative Process, http://characterology.ru/creatologia/philology/Rudnev_postmodernism/ (23.02.2018).

Stevenson, T. 2013. Bleeding Edge by Thomas Pynchon - Review. - The Guardian, 28.09, https://www.theguardian.com/books/2013/sep/28/bleeding-edge-thomaspynchon-review. 
RADCHENKO

Syundukov, N.; Svishchenko, K. 2016. Interview with Robin van den Akker. Metamodern, http://metamodernizm.ru/robin-van-den-akker/ (23.02.2018).

Tabbi, J. 1996. Postmodern Sublime: Technology and American Writing from Mailer to Cyberpunk. New York: Cornell University Press.

Tabbi, J. 2002. Cognitive Fictions. Minneapolis: University of Minnesota Press.

Tabbi, J. 2017. Pynchon: on the Reading Scene, behind the Scenes of the Letter. Paper presented at the public lecture, Kiev, December.

Timmer, N. 2010. Do You Feel It Too?: The Post-Postmodern Syndrome in American Fiction at the Turn of the Millennium. Amsterdam - New York: Rodopi.

Vermeulen, T.; Van den Akker, R. 2010. Notes on Metamodernism. - Journal of Aesthetics and Culture, 2:1, 24-39. https://doi.org/10.3402/jac.v2i0.5677

Vermeulen, T.; Van den Akker, R. 2015. Misunderstandings and clarifications. Notes on Metamodernism, http://www.metamodernism.com/2015/06/03/ misunderstandings-and-clarifications/ (23.02.2018).

Wallace, D. F. 1993. E Unibus Pluram: Television and U.S. Culture. - Review of Contemporary Fiction, 13:2, 151-194. 